\title{
Oliko se sittenkin Odysseuksen harharetki?
}

Juha Suorannan kirjoitukseni johdosta esittämät arvokkaat ajatukset ansaitsevat eräitä kommentteja - tuleehan näin tilaisuus myös kaivatulle tieteelliselle keskustelulle.

Mitä tarkoitinkaan, kun luonnehdin hänen tutkimusotettaan 'omaleimaiseksi'? Nykysuomen sanakirjan mukaan sanan merkitys ja käyttöyhteys liitetään omaleimaiseen tyyliin ja/tai ajattelutapaan. Kirjoittaessani Suorannan työn olevan varsin omaleimainen esitys modernissa suomalaisessa kasvatustieteessä viittaan erityisesti Suorannan tapauksessa erilaisuuteen, johonkin sellaiseen, mitä ei käsittääkseni kasvatustieteellisissä opinnäytetöissä ainakaan kovin laajalti ole nähty. Syytetäänhän kasvatustieteitä usein vanhoillisuudesta ja traditiosta kiinnipitämisestä, myös opinnäytetöissä.

Tätä taustaa vasten Suorannan yksikön ensimmäistä persoonaa suosivaa kirjoittamistyyliä voidaan kuvata omaleimaiseksi. En kuitenkaan tarkoita, etteivätkö muutkin kasvatustieteelliset väitöskirjat voisi olla omaleimaisia - Päinvastoin. Foucault'laisia vaikutteita saaneessa väitöskirjaan "Paljon vartijat"(1995) Hannu Simola päätyi vuorostaan kasvatustieteen traditiolle ominaisempaan ratkaisuun, perinteiseen monografiaan, jossa subjekti häviää passiivin taakse. Ehkäpä kasvatustieteellinen väitöskirjatraditio on kuitenkin yleisemminkin avartumassa; tuoreesta esimerkistä käy myös Jussi T. Kosken tarinankerronnan muotoon kirjoitettu "Horisonttiensulautumisia, Keskustelua Hans-Georg Gadamerin kanssa hermeneutiikasta, kasvamisesta, tietämisestä ja kasvatustieteestä" (1995).

Metodologinen pysähtyneisyyden aika näyttäisi siis vihdoinkin rakoilevan. Kasvatustieteitä pitkään dominoinut kvantitatiivinen lähestymistapa on hieman hellittänyt ja tilaa on annettu myös muille menetelmille. Metodologisesti painottuneiden väitöskirjojen, kuten esimerkiksi Suorannan, kontribuutio tieteenalalle onkin siinä, että ne välittävät uudenlaista tai ainakin toisenlaista ajattelua empiiriseen tutkimukseen. Puhuttaessa monitieteisyydestä ja tieteenalarajojen madaltamisesta - jopa raja-aitojen kaatamisesta - ei ole varaa fakkiutua metodologisesti, sillä se vaikeuttaa liikkumista tieteenalojen välillä, kuten Häyrynen totesi artikkelissaan "Kuinka välttää metodologinen lokeroituminen yhteiskuntatieteissä?" (Janus 4/1995).

Myös jonkinasteinen uuskiinnostus filosofisiin kysymyksiin on nähtävissä uusista väitöskirjoista. Sekä Jussi $\mathrm{T}$ Kosken että Jarmo Toiskallion väitöskirjassa "Tieto, sivistys ja käytännön viisaus" (1993) on vahvana ja jopa hallitsevaksi kuvattava (post)filosofinen viritys, mutta myös Suorannalla ja Simolalla on filosofisia painotuksia.

Yhtenäiskulttuurin murentumisen myötä tutkimuksen tekemisen mallit ovat laventuneet. Suorannan työ, kuten myös muidenkin, toimii siten esimerkkinä eräästä mahdollisesta tavasta tehdä opinnäytetyö. Tosin on muistettava, että se mikä sopii toiselle ei välttämättä sovi toiselle. Suorannan kehittelemä soppa on, kuten jo arviossani totesin ja kuten Suorannan väitöskirjan tarkastusta seuranneissa juhlallisuuksissakin todettiin, nieltävissä, koska hän kirjoittaa hyvin, rohkeasti, rehellisesti ja avoimesti. Nähdäkseni Suorannan työ pysyy niin sanotusti 'kasassa', eikä otsikossani viitatusta harharetkestä ole mielestäni merkkejä.

Puheena oleva kysymystä omaleimaisuudesta voidaan lähestyä myös tieteenfilosofisesta näkökulmasta. K.R. Popperin "Arvauksia ja kumoamisia - tieteellisen tiedon kasvu" -teoksessa (1995, alkupainos 1963) esittämän kuuluisan teesin mukaan tutkijoita voidaan ajatella olevan 
lähinnä kahdenlaisia. Näistä suurempi ryhmä muodostaa tieteen puurtamiseen erikoistuneen massan. Tieteellisen massan tehtävänä on yrittää kumota, osoittaa vääräksi tai löytää puutteita pienempään ryhmään kuuluvien tutkijoiden esittämistä ajatuksista. Tämä pienempi ryhmä muodostuu spekulatiivisemmin ja innovatiivisemmin asennoituneista tutkijoista tai ajattelijoista, joiden esittämien uskaliaiden teorioiden välityksellä tiede voi - ainakin jossain mielessä - kehittyä. Käyttäessäni termiä 'omaleimainen', on kai selvää kumpaa ryhmää arvioimani työ lähestyy.

TS. Kuhnin "Tieteellisten vallankumousten rakenteessa" (1969) omaksutun terminologian mukaan voimme puhua kahdenlaisista tutkijoista, tyrannian alaisuudessa puurtavista normaalitieteilijöistä ja toisaalta normaalitiedettä vastustavista vallankumouksellisista. Tässä tarinassa Suorannan väitöskirja kuulunee kaiketi kasvatustieteen Bastiljin linnakkeen kaatajiin tai muurin relativistisiin nakertajiin.

Ehkä on syytä vielä nostaa esiin eräs seikka, joka liittyy yleisemminkin tehtyihin tutkimusten arviointeihin, ja johon Suorantakin viittaa kirjoittaessaan tekstien alkavan elää omaa elämäänsä varsinaisen luomisensa jälkeen. Tuskin kenelläkään kirjoittajalla on oikeutta tai edes järkeviä perusteita vaatia tekstinsä ymmärtämistä juuri niin kuin se oli "tarkoitettukin". Tämä problematiikka hahmottuu nähdäkseni hermeneuttisen läsnäolon käsitteen avulla, joka tarkoittaa gadamerilaisittain "alituista toisinymmärtämistä, loputonta toisinolemista, läsnäolon identtisen toistumisen mahdottomuutta. Tekstin tai asian mieltä ei voida koskaan saattaa tyhjentävällä tavalla läsnäolevaksi; mielen näyttäytyminen tulkinnassa kuuluu alkuperäisesti yhteen oman kätkeytymisensä kanssa. jokainen tulkinta on nimittäin tietystä rajallisesta horisontista tapahtuvaa, perspektiivistä tekstin mielen ymmärtämistä. Ymmärtämättä jää aina tietty toisinolemisen potentiaalisuus, joka pysyy jokaisen yhteistä asiaa koskevan ymmärtämisaktin tavoittamattomissa." (lainaus Nikander niin \& näin 3/ 1995).

On totta, että H.G. Gadamer on Totuus ja Metodi teoksessaan puhunut myös horisonttien yhteensulautumisesta ymmärtämisessä, mutta kahden eri henkilön horisonttien identtisyys näyttää kuitenkin olevan mahdotonta olivatpa kirjan kirjoittajan ja sen arvioijan pyrkimykset kuinka hyväntahtoisia tahansa.

Kirjoituksesta on jätetty tarkemmat lähdeviittaukset sekä erillinen kirjallisuusluettelo pois toimituksen pyynnöstä.

\section{Sari Husa}

